https://helda.helsinki.fi

\title{
Social Aspects of Scientific Knowledge
}

\author{
Niiniluoto, llkka
}

2020-01

Niiniluoto , I 2020 , ' Social Aspects of Scientific Knowledge ', Synthese , vol. 197 , no. 1 , pp. 447-468 . https://doi.org/10.1007/s11229-018-1868-7

http://hdl.handle.net/10138/309758

https://doi.org/10.1007/s11229-018-1868-7

submittedVersion

Downloaded from Helda, University of Helsinki institutional repository.

This is an electronic reprint of the original article.

This reprint may differ from the original in pagination and typographic detail.

Please cite the original version. 


\title{
Social Aspects of Scientific Knowledge
}

\author{
Ilkka Niiniluoto
}

\begin{abstract}
From its inception in 1987 social epistemology has been divided into analytic (ASE) and critical (CSE) approaches, represented by Alvin I. Goldman and Steve Fuller, respectively. In this paper, the agendas and some basic ideas of ASE and CSE are compared and assessed by bringing into the discussion also other participants of the debates on the social aspects of scientific knowledge - among them Raimo Tuomela, Philip Kitcher and Helen Longino. The six topics to be analyzed include individual and collective epistemic agents; the notion of scientific community; realism and constructivism; truth-seeking communities; epistemic and social values; science, experts, and democracy.
\end{abstract}

KEYWORDS. democracy, epistemic values, experts, scientific community, scientific realism, social epistemology, truth-seeking,

\section{Introduction: Analytic and Critical Social Epistemology}

Social epistemology studies knowledge from a social point of view. As a complement to empirical studies, such as the sociology of knowledge and the sociology of science, social epistemology aims to provide a normative philosophical account of knowledge as a collective achievement. Even though the term dates from the 1950s, the work in this field started in 1987 with a special issue of Synthese, edited by Frederick Schmitt, and the new journal Social Epistemology - A Journal of Knowledge, Culture, and Policy, founded by Steve Fuller. In the next year Fuller published a monograph with the title Social Epistemology. Alvin I. Goldman, who published in the 1987 Synthese issue an article on "Social Epistemics", developed his reliabilist epistemology in the direction of social practices in his Knowledge in a Social World (1999). These studies attracted many other epistemologists and 
philosophers of science as well. In the opening article of the new journal Episteme - A Journal of Individual and Social Epistemology, Anthony Quinton (2004) distinguished Goldman's and Fuller's approaches as the two main rivals of this new discipline, calling them Analytic Social Epistemology (ASE) and Critical Social Epistemology (CSE), respectively. ${ }^{1}$

The communication between ASE and CSE has been largely dysfunctional and rhetorically ineffective. Fuller (2012) argues that ASE has failed to make significant progress, as it is basically conservative and lacks understanding of actual knowledge processes. Goldman (1999), who refers to Fuller only in a footnote, claims that Fuller with many sociologists of science suffers from "veriphobia". Goldman and Dennis Whitcomb, in their edited book Social Epistemology: Essential Readings (2011), mention only the early work Fuller (1988) in their extensive bibliography. Finn Collin (2011) has given a careful assessment of rival approaches, including a whole chapter on Fuller, but he concludes that science studies should adopt a "realist, veritistic, and reliabilist view of science".

The tension between ASE and CSE can be seen to arise from a difference in the personalities of their main proponents: while Goldman is a careful and even pedantic analytic philosopher, Fuller is lively thinker who loves to be provocative. In my view, Fuller has not properly appreciated the richness and prospects of the growing analytic program, but on the other hand Fuller's own position is hard to classify in standard philosophical terms. The main difference between the two approaches appears to be their distinctive agendas, but these agendas may reflect deeper differences within the underlying ontological, epistemological, methodological, ethical and political standpoints.

The six topics to be analyzed in this paper include individual and collective epistemic agents (Section 1), the notion of scientific community (Section 2), realism and constructivism (Section 3), truth-seeking communities (Section 4), epistemic and social values in science (Section 5), science, experts, and democracy (Section 6). While Fuller has been skeptical about Goldman's way of treating collective epistemic agents, there is clearly a need to make the analytic models of collective knowledge sociologically more realistic. For this reason, ASE and CSE are compared in this paper by bringing into the discussion also other

\footnotetext{
${ }^{1}$ In this paper I cannot discuss David Bloor's Strong Programme as an important strand of social epistemology (but see Niiniluoto 1999, pp. 252-267). For defenses of the Edinburgh school, see Kusch $(2011,2018)$.
} 
participants of the debates on the social aspects of scientific knowledge - among them Raimo Tuomela, Philip Kitcher, and Helen Longino.

\section{Individual and Collective Epistemic Agents}

Steve Fuller's new journal Social Epistemology in 1987 was announced to be based on "the assumption that a key feature of a claim's epistemological status is its need to be certified by an appropriate social group before passing as knowledge". In his review 25 years later, Fuller (2012) declares that his starting point has been "the elusiveness of consensus in science". In spite of such reservations about the idea of consensus, the main line of Critical Social Epistemology is to consider social groups as the carriers of knowledge.

Starting with Plato's definition of episteme, traditional epistemology attributed knowledge to individual subjects: knowing that as a propositional attitude is a relation between an individual $\mathrm{X}$ and a proposition $\mathrm{p}$ so that (i) $\mathrm{X}$ believes that $\mathrm{p}$, (ii) $\mathrm{p}$ is true, and (iii) $\mathrm{X}$ has justification for $\mathrm{p}$. Condition (iii) was typically spelled out by requirements that $\mathrm{X}$ can prove that $\mathrm{p}$, or $\mathrm{p}$ is evident for $\mathrm{X}$, or $\mathrm{X}$ can reliably perceive that $\mathrm{p}$. Modern philosophers, who developed empiricist and probabilistic theories of knowledge, recognized that in many everyday activities our knowledge has to rely on the testimony of other people. Thus, $\mathrm{X}$ has justification for $\mathrm{p}$ if $\mathrm{X}$ learns that $\mathrm{p}$ from a testimony. For example, in a court one can trust the testimony of two independently agreeing witnesses, and in education we can trust the testimony of the best scientists.

The notions of trust and testimony have been important topics in Analytic Social Epistemology, as one can see in the contents of the representative collection Social Epistemology (2010), edited by Haddock, Millar, and Pritchard (cf. Goldman 2010). In such studies, the doxastic or epistemic agent is an individual who receives input - via agreement and disagreement - from other members of a community. Goldman's Knowledge in a Social World (1999) investigates which "social practices will promote knowledge rather than subvert it", but is still for the most part based on the model of individual epistemic agents, as "collective entities as potential knowing agents" are only rarely discussed (ibid., p. 5). At this point Fuller's general criticism has been that Goldman's treatment is too squarely based on 
methodological individualism, too aprioristic and formalistic, and too close to the standard notion of rational agent in microeconomics, while Fuller has not really developed his alternative of methodological holism. However, in the recent collection of "essential readings" in ASE Goldman makes room for approaches with collective doxastic agents and systems by including essays of Christian List on judgment aggregation in groups and Philip Pettit on "Groups with Minds of Their Own" (see Goldman and Whitcomb 2011).

The notions of belief and knowledge have been extended to collective agents in analytic studies of social groups (see Tuomela 1984; Gilbert 1989; cf. Niiniluoto 2003). Raimo Tuomela (1995) further defines the notion of "we-intention" for social groups. The concept of group belief would not be very interesting, if it were simply reduced to the summative condition that all members (or the majority of members) of G believe that $\mathrm{p}$. Let us denote this by $\mathrm{B}_{\mathrm{Gp}}$ :

(1) $\mathrm{B}_{\mathrm{G}} \mathrm{p}=$ for every a in $\mathrm{G}, \mathrm{B}_{\mathrm{a}}$.

where $B_{a} p$ means that a believes that $p$. Such a numerical condition could be applied to any accidental collection of individuals, and it would fail to express the idea that there are relations or ties between the members of the group, so that the belief of a group is a sort of social or joint action. An influential new approach was suggested by David Lewis (1969) in his analysis of "conventions". According to Lewis, group commitments as conventions involve iterated epistemic or doxastic operators. In this sense, it is common knowledge in community $\mathrm{C}$ that $\mathrm{p}$ if and only if (almost) everyone in $\mathrm{C}$ has reason to believe that $\mathrm{p}$ and (almost) everyone in $\mathrm{C}$ has reason to believe that (almost) everyone in $\mathrm{C}$ has reason to believe that $\mathrm{p}$.

Margaret Gilbert (1989) defines group beliefs by joint acceptance, where a group G jointly accepts that $p$ if and only if "it is common knowledge in $G$ that the members of $G$ individually have intentionally and openly expressed their willingness to accept that $\mathrm{p}$ with the other members of G as a body". Tuomela (1995) in turn defines mutual belief that $\mathrm{p}$ in a group $\mathrm{G}$ by the requirement that all members of $\mathrm{G}$ believe that $\mathrm{p}$, all members of $\mathrm{G}$ believe that all members of $\mathrm{G}$ believe that $\mathrm{p}$, etc. 


$$
\mathrm{MB}_{\mathrm{G}}=\mathrm{B}_{\mathrm{G}} \mathrm{p} \mathrm{B}_{\mathrm{G}} \mathrm{B}_{\mathrm{G}} \mathrm{p} \text {... }
$$

To avoid the idealization that group beliefs always involve an infinite number of sub-beliefs, Tuomela suggests that the number of iterations of the operator $\mathrm{B}_{\mathrm{G}}$ can be stopped at some finite number $\mathrm{n}$, and after $\mathrm{n}$ it is required that the members of $\mathrm{G}$ are disposed to form a similar belief at the level $\mathrm{n}+1$ (ibid., p. 43). Then the shared we-belief that $\mathrm{p}$ in group $\mathrm{G}$ is defined by the condition that every member of $\mathrm{G}$ believes that $\mathrm{p}$ and also believes that it is a mutual belief in $\mathrm{G}$ that $\mathrm{p}$ :

$$
\text { For every } \mathrm{a} \text { in } \mathrm{G}, \mathrm{B}_{\mathrm{a}} \mathrm{p} \text { and } \mathrm{B}_{\mathrm{a}} \mathrm{MB}_{\mathrm{G}} \mathrm{p}
$$

(ibid., p. 325). However, (3) is equivalent to $\mathrm{B}_{\mathrm{G}} \mathrm{p} \& \mathrm{~B}_{\mathrm{G}} \mathrm{MB}_{\mathrm{G}} \mathrm{p}$, so that (2) and (3) are essentially the same condition - with the only difference that (3) contains one more iteration of the $\mathrm{B}_{\mathrm{G}}$-operator than (2).

The notion of shared we-belief is egalitarian in the sense that it is completely symmetric with respect to the group members. Tuomela contrasts it with what he calls proper group beliefs which assume some hierarchical authority system in the group. He divides the group $\mathrm{G}$ into a set $\mathrm{H}$ of "operative agents", whose social role is to form the views of the whole group $\mathrm{G}$, and to "non-operative agents" in $\mathrm{S}=\mathrm{G}-\mathrm{H}$ who accept the views of $\mathrm{H}$ on the basis of their authority. The non-operative members in $\mathrm{S}$ are assumed to be full-fledged and adequately informed about the beliefs of the operative members in $\mathrm{H}$, and their beliefs are based upon information about the beliefs of H (ibid., p. 319). Tuomela characterizes the epistemic position of the members of S as "tacit acceptance" A which is weaker than belief B or explicit acceptance (ibid., p. 327). Then, with some simplifications, group G believes that $\mathrm{p}$ if and only if every member of $\mathrm{H}$ believes that $\mathrm{p}$, there is a mutual belief among $\mathrm{H}$ that every member of $\mathrm{H}$ believes that $\mathrm{p}$, all members of $\mathrm{S}$ tend to tacitly accept $\mathrm{p}$, and there is a mutual belief in the whole group $\mathrm{G}$ that all members of $\mathrm{S}$ tend to tacitly accept $\mathrm{p}$ (ibid., $\mathrm{p}$. 315). More formally, these conditions can be expressed by 
(4) $\quad \mathrm{MB}_{\mathrm{Hp}} \& \mathrm{Asp}_{\mathrm{s}} \& \mathrm{MB}_{\mathrm{G}} \mathrm{A}_{\mathrm{sp}}$.

Thus, the key idea of this account is that the members of $S$ are willing to learn from the operative members of $\mathrm{H}$.

Definition (4) could be modified so that, instead of using the new category of "tacit belief", the members of S have conditional beliefs or conditional commitments to beliefs, given beliefs about the opinions of the authorities. These conditional formulations allow that a group $\mathrm{G}$ believes that $\mathrm{p}$ even though only the subgroup $\mathrm{H}$ of $\mathrm{G}$ actually (mutually) believes that $p$, while the rest of the group would believe that $p$ on some additional conditions.

Refinements of condition (4) could be formulated in terms of probability theory. Our willingness to learn from other persons depends on their reliability, i.e., on the probability that they are speaking the truth (cf. Kitcher 1993). Lehrer and Wagner (1981) consider groups where members give weights to each other, and then modify their personal probability of $p$ by a method of iterated aggregation. One person respects another if the associated weight is non-zero. They show that group consensus does not presuppose positive respect between all pairs of members in the group: the aggregation method converges to a consensual probability of $p$, assuming that there a chain of positive mutual respect between all members of the group.

Assuming that we have succeeded in analyzing group beliefs, group knowledge could be defined by adding the truth condition and a collective justification condition:

$$
\mathrm{K}_{\mathrm{G}} \mathrm{p}=\mathrm{B}_{\mathrm{G}} \mathrm{p} \& \mathrm{p} \& \mathrm{~J}_{\mathrm{G}} \mathrm{p}
$$

where $J_{\mathrm{G}}$ states that the group $\mathrm{G}$ has a justification for $\mathrm{p}$. Gilbert (1989), p. 314, suggests briefly that $\mathrm{J}_{\mathrm{G}} \mathrm{p}$ might be analyzed by the requirement that there is some condition $\mathrm{j}$ such that the members of $G$ jointly accept $\mathrm{j}$ as a justification for $\mathrm{p}$. If $\mathrm{J}(\mathrm{j}, \mathrm{p})$ means that $\mathrm{j}$ is a justification for $\mathrm{p}$, then this requirement could be defined in terms of mutual beliefs:

(6) $\quad J(j, p) \& M B_{G} J(j, p)$. 
Alternatively, instead of this kind of shared we-justification, (6) could also reflect the authority structure in group G: in analogy with Tuomela's proper group belief (4), $\mathrm{j}$ is accepted as a justification for $\mathrm{p}$ by the operative members $\mathrm{H}$ of $\mathrm{G}$, and the other nonoperative members in $\mathrm{S}$ accept $\mathrm{j}$ as a justification for $\mathrm{p}$ on the authority of $\mathrm{H}$.

Again, the authority account could be modified so that the members of $S$ do not know the justification $\mathrm{j}$ that $\mathrm{H}$ has found for $\mathrm{p}$, but they would accept it if they knew it. In other words, the members of $\mathrm{S}$ trust the authorities in $\mathrm{H}$, when the representatives of $\mathrm{H}$ claim to have evidence for $\mathrm{p}$. This is typical in everyday life, when we rely on the testimony by eyewitnesses or official broadcasting companies. As we shall see in Section 6, this kind of authority structure is important also in the case of science.

\section{The Scientific Community as a Collective Epistemic Agent}

Historically the most important example of a collective epistemic agent comes from science. With the progress of science during the Renaissance, it was realized that science is a form of social knowledge whose results are produced by the joint action of investigators. This led to the insight that the proper subject of scientific knowledge is the scientific community (cf. Niiniluoto 2003).

The vision of science as a cooperative activity was expressed by Francis Bacon in the Salomon's House of The New Atlantis in 1627. The Royal Society in the 1660s provided in practice a model of a research institution (see Shapin and Shaffer 1985). Together with the establishment of scientific journals, it served to define the classical ethos of science (cf. Merton 1973). With the gradual institutionalization of science the professional role of a scientist was finally defined in the nineteenth century (cf. Ben-David 1971). From the perspective of Durkheimian social anthropology, the institution of science can be seen to involve both individual and collective agents (see Douglas 1986).

The notion of the "scientific community" is often traced to articles published by Michael Polanyi and Robert Merton in 1942. Polanyi considered a "society of explorers" as an invisible collectivity that evolves its own norms and policies (see Polanyi 1967). This leads naturally to the sociological definition of the scientific community as "the network of 
communication and social relationships between scientists working in given fields or in all the fields" (Ben-David 1971, p. 3; Hagstrom 1965).

Thus, the widest macro-sociological conception identifies the scientific community (in the singular) with the collectivity of the actually existing scientists in all fields of research. A narrower approach is favored by Thomas Kuhn (1970), p. 177, who takes a scientific community to consist of the practitioners of a scientific specialty (e.g., physicists, astronomers). According to Kuhn, in "normal science" the members of such a community share a "paradigm", so that conversely a scientific community can be defined as a group which shares a paradigm. Even narrower definitions of scientific communities (in the plural) divide disciplines into areas of subject matters, such as physical optics and electricity, yielding groups with typically about one hundred specialists as their members (ibid., p. 178).

Science can be viewed as a cooperative activity also on a micro-sociological level: most work in natural science, medicine, and psychology is based on the activities of research groups. The members of such groups usually get their salaries from the same employer, conduct experiments together, and publish research reports with joint authorship.

The micro-sociological definitions are institutional in the sense that they identify the scientific communities with historically existing finite groups of persons who work together in the same place or at least are trying to jointly solve the same research problems. The membership of such groups is usually definable in an unambiguous way. But the wider disciplinary definitions are already problematic. While it may be easy to agree that painters, dancers, politicians, and priests do not constitute scientific communities, what is the status of such professions as engineers, economists, and historians? How do we distinguish science from pseudo-scientific activities like astrology and scientology?

The latter issue is known as the demarcation problem of distinguishing science from non-science (see Niiniluoto 1984, Ch. 1). Some of the proposed criteria are epistemological in the sense that they refer to the special kind of knowledge that is supposed to be achievable in science. For example, Norman Campbell in What is Science? (1921) defined science as "the study of those judgments concerning which universal agreement can be obtained". Some criteria are methodological in the sense that they refer to specific types of methods that are applied in science. For example, in 1934 Popper characterized scientific hypotheses as those 
which are in principle falsifiable by observational statements (cf. Popper 1963).

Methodological characterizations of science were anticipated already by the pragmatist Charles S. Peirce in his "The Fixation of Belief” in 1878. Peirce described science as the pursuit of truth by using the "self-corrective" method. He argued that the ultimate opinion of "all who investigate" is fated or destined to converge to the truth, provided they are using the scientific method ( $C P$ 5.407): "truth is that concordance of an abstract statement with the ideal limit towards which endless investigation would tend to bring scientific belief" (CP 5.565). In "The Doctrine of Chances" (1878), Peirce stated that "logic is rooted in the social principle": in order to guarantee that the process of investigation carries different minds to the same conclusion, we have to identify our interests "with those of an unlimited community" (CP 2.654).

Peirce's early definition introduces the scientific community as an ideal epistemological concept which is not restricted by time and place. Rather, the membership is open to anyone who identifies his or her interests with the pursuit of truth, and this ideal community has actual, past, future, and even potential members. This philosophical notion is thus broader than any sociological definition of a community. Peirce's approach has been followed by Karl-Otto Apel (1980) and Jürgen Habermas (1998) who employ the conception of the ideal communication or discourse community in their "transcendental pragmatics".

Even though the ideal communities of Peirce and Habermas have to be distinguished from actually existing groups and auditories, they may still serve as ideal types in Max Weber's sense: real scientific collectives may be compared to the normative standards. And the methodological and ethical norms, even though they are sometimes violated by the actual behavior of the scientists, may still be in force in the sense that they are accepted as valid constitutive requirements for good science - and violation of the good practice of science may lead to sanctions.

The definition (5) of group knowledge $\mathrm{K}_{\mathrm{G}} \mathrm{p}$ involves the condition that $\mathrm{p}$ is true. In practice, we do not have direct access to the truth values of propositions (cf. Section 4), and for fallibilists like Peirce and Popper the best indicator of truth is the assessment of the scientific community. Popper emphasized that a theory can "temporarily and tentatively be accepted as part of current scientific teaching" only if it is able to withstand critical 
discussion by the scientific community better than its competitors (Popper 1972, p. 261). This more flexible time-dependent notion of scientific knowledge can be given in institutional terms. Following the Lewisian idea of conventions, one can develop a general "conventionalist" theory of social institutions (Lagerspetz 1989; cf. Searle 1995): an institution I exists for a community $\mathrm{C}$ if and only if the members of $\mathrm{C}$ jointly accept (or mutually believe in) the existence of I. Examples of such institutions could include money, the legal order in a country, and language as a system of norms. Martin Kusch (1993) suggests that "folk psychology" could be understood as a social institution. Similarly, an institutional account of scientific knowledge states that

(7) Proposition $\mathrm{p}$ belongs to the scientific knowledge at time $\mathrm{t}$ $=$ The scientific community at time $t$ accepts $p$ as true.

For example, quantum mechanics belongs to the scientific knowledge of our age if and only if the present scientific community accepts quantum mechanics as true. Those antirealist philosophers, who do not think that science seeks the truth, can drop the last two words "as true" in (7). This is what in fact happens with Fuller, when he states that "having knowledge is ultimately a matter of having credibility" in the sense that fellow researchers use their resources to follow up or cite the work of another researcher (see Fuller 1988, p. 30).

We shall return to this institutional account in Section 5. Here it is interesting to link definition (7) to the analysis of Section 2. Brad Way (2007) has argued that scientific knowledge can be possessed only by research teams, not by specialty communities or the scientific community as a whole. It is correct that research groups may have joint knowledge, if community acceptance is analyzed by an egalitarian model like (3). But the virtue of the alternative approach (4) with the distinction between operative and other members is that the institutional definition (7) makes sense for the wide sociological concept of the scientific community.

\section{Realism and Constructivism}


One of the underlying differences between ASE and CSE concerns the ontological conception of reality. Goldman is a well-known scientific realist who accepts the independent existence of the natural world and the possibility of finding objective truths about reality (see also Kitcher 1993; Niiniluoto 1999). Among his enemies he mentions various kinds of "constructivists" and "revisionists", including Fuller in this group.

This somewhat crude classification does not do justice to Fuller's intricate position. His 1988 work shows his broad knowledge of contemporary currents within the philosophy of science. Fuller distances himself from the scientific realists by concluding that "antirealism would seem to be the ultimate solution to the problem of realism" (Fuller 1988, p. 98). But he adds that "although sociologist of knowledge are, understandably, antirealists about the entities produced by physicists, they need not be antirealists about social entities as well" (ibid., p. 65). This combination of theoretical antirealism about nature and realism about society is repeated in his next book Philosophy of Science and Its Discontents (1989), p. 3, but it need not imply an antirealism about our everyday material environment. At the same time, Fuller criticizes sociologists of science, such as "New Wavers" (Bruno Latour and Karin Knorr-Cetina) and "the Strong Programme" of the Edinburgh School of David Bloor and Barry Barnes, for their inability to adequately treat normative questions about science. As his own alternative, Fuller proposes a "panglossian epistemology" which studies the actual production and distribution of knowledge through its material embodiments (see Fuller 1993). This approach may be motivated by Fuller's ontological stance, but it is criticized by Helen Longino for the loss of genuine normative questions about knowledge (Longino 2002a, p. 172).

Fuller (2004) continues the debate between ASE and CSE in his article on "Descriptive vs. Revisionary Social Epistemology". According to him, ASE is conservative or "descriptive" in the sense that it wishes to justify the world as it is, while the "revisionary" CSE studies how to construct alternative realities and futures. Antirealism for Fuller means "to treat reality as something resisted and overcome rather than accepted and imitated". In Fuller (2012), he characterizes himself as a "realizationist": "I believe that we increasingly come to turn into reality whatever we conceive". As an instance of this "proactionary" attitude he mentions the transhumanist project of creating "Humanity 2.0". For CSE, this 
recommends the task of socially constructing epistemic standards (rather than assessing knowledge claims by already accepted standard), which is in harmony with the original framework of the journal Social Epistemology to use empirical research "as a guide for directing contemporary knowledge enterprises".

As a comparison between ASE and CSE this account is suggestive but problematic. The scientific realists typically assume that there are mind-independent features and laws about the natural world, but they also acknowledge the possibility of manipulating nature and transforming reality into material artefacts. They may also follow Popper (1972) in accepting in their ontology a human-made "World 3" of cultural and social institutions and abstract entities (see Niiniluoto 2006). Such philosophers are realists about nature as well as society. Further, they need not be determinists, so that they can conceive the future as an open "tree" with many not-yet-realized possibilities.

It is also pertinent to remark that ontological realism is compatible with conceptual pluralism: the world can be categorized in alternative ways with different conceptual frameworks, but still we can maintain the correspondence theory of truth (see Niiniluoto 1999, Tambolo 2014). Philip Kitcher, with his new interests in social issues about science and democracy, has moved from his earlier "monism" (i.e. the world has a unique structure which can be represented in a complete theory) to "modest realism" which combines truth as correspondence with conceptual relativity (see Kitcher 2001; Diéguez 2011). His 2001 book includes chapters on "the world as find it" and "the world as we make it". As our concepts draw new boundaries in nature, "science, or, more generally, inquiry, is constitutive of the world in which we live" (Kitcher 2011).

\section{Truth-Seeking Communities}

Alvin Goldman's epistemology characterizes justification by the reliability condition: a belief is justified if it is obtained by a reliable process, where "the reliability of a practice is measured by the ratio of truths to total number of beliefs a practice would foster" (Goldman 1987, p. 128). This is in line with Peirce's account of probability in terms of truthfrequencies: a mode of argument can be assessed by its ability to yield true conclusion from 
true premises. So, for example, the truth-frequency of deductive entailment is one, and color perception in normal circumstances gives a correct belief in almost all cases. A detailed account of this "veritistic epistemology" is given in Goldman (1999).

Goldman's approach can be compared to other recent analyzes of truth-seeking and truth approximation. Following Popper (1963) and Levi (1968), many scientific realists point out that the aim of science should be a balance between truth and information. In science, we are not interested in just any truths, such as trivial tautologies, but rather in informative truths which describe and explain reality. And, as science is a fallible enterprise with a risk of error, we aim at hypothetical theories which are close to the truth. Popper (1972) tried to capture these ideas with his notion of truthlikeness or verisimilitude (see Niiniluoto 1987). This approach gives an alternative to Goldman's version of veritism, where the success and progress of epistemic practices is measured by increasing truthlikeness (see Niiniluoto 1984, 1999). Thus, Goldman's "V-values" as truth-ratios or truth-frequencies are replaced by measures of truthlikeness or their estimates. In this spirit, one can study the veritistic value of logical models of belief revision and dynamic doxastic logic (van Ditmarsch et al. 2007), which usually have been defined in terms of consistency and preservation of information instead of truth (see Niiniluoto 2011). Another application is to study whether belief merging (i.e. combining two possibly conflicting belief systems into one) is a successful method of truth approximation (see Cevolani 2014).

Goldman's veritism - or its alternatives - can formally be applied within the context of individualist epistemology, but it has a natural extension to social epistemology. Thus, ASE studies "social practices in terms of their impact on the truth-values of agents' beliefs" (Goldman 2010). Related work on "opinion dynamics" (Hegselmann and Krause 2006) has been done by using sophistical computer simulations. This project can be combined with the institutional characterization of science, given by the condition (7). Some reservations to “consensualism” were given already by Goldman (1987), since mere agreement or consensus of a community is not sufficient to warrant that its outcome is qualified as knowledge. If we wish to speak about scientific knowledge, not just about scientific beliefs, the sociological definition of the scientific community should allow a reference to the scientific method: the consensual acceptance of $\mathrm{p}$ should be justified in the sense that the community has applied 
the critical methods of scientific inquiry to test the correctness of $p$, and $p$ has turned out to be the best available hypothesis in the light of this scrutiny.

Goldman (1999) attacks all "veriphobic" approaches which talk about institutionalized beliefs without introducing the requirements of truth and justification. The tendency of reducing scientific knowledge merely to the collective beliefs of scientists is illustrated by the sociologists of science. The Edinburgh School starts from the methodological symmetry principle, which states that all beliefs - true or false, rational or irrational - should be explained by same kinds of social reasons, so that the empirical study of science is not based on any prejudice on the credibility and objectivity of science. Also Latour's laboratory studies slide from not assuming that science is rational to assuming that science is not rational (see Niiniluoto 1999, p. 270). In the STS-studies of science, technology and society, the most popular message has been that "scientific knowledge has no privileged claim to truth", all belief systems are "on a common epistemological footing", and the scientists are not guardians of objective knowledge but "hired brains of special interests and lobbyists of their own" (see Cozzens and Woodhouse 1995). In contrast, Goldman's scientific realism promises to give an argument for the thesis of "comparative scientific superiority" that "scientific practices are veritistically better than any set of non-scientific practices" (Goldman 1999, p. 247; cf. Kitcher, 1993). This debate was one of the main issues of the Science Wars in the 1990s.

It should be remembered that the scientific realists have been fighting in another front within the philosophy of science against instrumentalists (who deny that theories have truth values), constructive empiricists (who restrict the truth requirement to observational statements), pragmatists (who give up the correspondence theory of truth), and epistemological anarchists (who reject the notion of truth altogether). Thomas Kuhn argued that a theory-independent notion of truth is incoherent, and Larry Laudan followed him in defining scientific progress by the problem-solving capacity of scientific traditions.

It was the antirealist Laudan (1977) who introduced the "arationality principle" that "the sociology of knowledge may step in to explain beliefs if and only if those beliefs cannot be explained in terms of their rational merits". However, for Laudan truth is a utopian goal, and the rationality of a belief does not equal its truth. Thus, when Helen Longino (2002a) 
interprets "the rational - social dichotomy" so that some realist philosophers tend to "equate social forces with "bias"”, Kitcher (2002) quickly replies that for him and Goldman social factors need not be contrary to the rationality and progressiveness of the sciences. Indeed, it is up to the program of ASE to study which social practices are truth-conducive and which are not.

Fuller (2012) complains that Goldman mislabels his position as "veriphobic". Fuller's background in post-Kuhnian philosophy of science and the STS-studies, and his instrumentalist antirealism, can be seen in a little book Science (1997), which argues that the sciences pretend to have a privileged access to the nature of reality, but strategically misinterpret their own history and fail to live up to their own ideals of rationality. But Fuller (2003) also argues that in the Kuhn - Popper debate in the 1960s it was Popper who gave a better account of the aims and ambitions of science. So, on the whole, it appears that Fuller is not so much occupied with the debates on realism and the notion of truth, but rather is more interested in questions concerning the distribution of knowledge (see Section 6).

\section{Epistemic and Social Values}

Starting in the late 1930s, a classical analysis of the normative structure of science was given by the sociologist of science Robert K. Merton (see Merton 1973). He argued that "the ethos of science" is constituted by the norms of "universalism, communism, disinterestedness, and organized skepticism". He also analyzed the reward system of science which gives recognition to the scientist who has first published a research discovery. This reward system is operated by the practice of scientific journals to publish papers on the basis of peer review. Even though the competition for resources in science has become more and more intense, quality assurance is still largely accomplished by referees and panels representing peers from the scientific community.

Many later sociologists have challenged the validity of Merton's ethos in the new environment of commercially oriented Big Science (see Ziman 1994). In particular, the ideas of impersonality and disinterestedness have been questioned, and case studies have been presented to show that at least sometimes social interests have influenced the success of some 
scientific opinions. Fuller (1988), p. 12, points out that "Old Wave sociology of knowledge" had an equivocal reading of the thesis that all knowledge is "interest-laden", since it failed to distinguish three different groups in relation to the acceptance of a knowledge claim: motivators (who hope that they might benefit), benefitters (who actually benefit), and users (who use the claim in proposing other knowledge claims). But one should distinguish the actual behavior of scientists in various circumstances and the norms governing their actions. It is still a fundamental principle of science that a knowledge claim cannot be supported or justified by appealing to its potential in satisfying some personal, political, economical, or religious interests. Violations of this norm of objectivity, if detected, will be corrected by other scientists.

These observations suggest that the norms of science are social institutions in the sense discussed in Section 2. Speaking generally,

(8) Principle $\mathrm{n}$ is a norm of science if and only if $\mathrm{n}$ is jointly accepted by the scientific community.

This means that all (or most) members of the scientific community follow $\mathrm{n}$ in their behavior and expect that all (or most of) the other members follow n. A similar analysis can be given of the values of science: they are not simply virtues or attributes of individual scientists but institutional commitments. For example, the guiding principles of research ethics include the values of honesty (against fraud and fabrication of data), fairness (against plagiarism), and responsibility (concern for environmentally, culturally or socially harmful applications of science) (see Niiniluoto 2007). Research integrity is not only a property that a scientist may or may not have, but a social norm about good scientific practice whose violations (misconduct and fraud) are in many countries examined and sanctioned by special ethical committees or advisory boards.

In this normative sense, universities and research institutions are value-based organizations whose ethos includes goals like truth, knowledge, critical attitude, creativity, autonomy, and social responsibility. Scientific research is governed by epistemic or evidential norms which concern public observability of research data, repeatability of 
experiments, and empirical testability of theories. Following Carl Hempel's terminology, it is often said that the epistemic utilities, or the standards for assessing quality of success in knowledge-seeking, include truth, information, scope, truthlikeness, consistency, coherence, confirmation, understanding, explanatory power, predictive power, accuracy, and simplicity. These epistemic values are intrinsic indicators of truth, so that their institutional acceptance satisfies Goldman's idea of veritistic ASE.

Helen Longino (2002a), who argues that science as social knowledge is value-laden, adds to the epistemic principles social norms governing the critical discursive interactions between the community of investigators. These norms concern the availability of venues for criticism, responsiveness for criticism, publicly recognized standards for evaluating inquiry, and tempered equality of intellectual authority. We shall return to the last condition in Section 6, but otherwise we see that her conditions resemble Popper's (1963) plea for critical discussion and Habermas's (1998) model of ideal discourse. What is more, Longino's norms can be seen to promote the attainment of truth, so that they also satisfy the aims of ASE.

In the same way, one can argue that the ethical norm of honesty is an "extrinsic epistemic value" in the sense that its validity in the scientific community helps to eliminate errors and achieve truths (see Rolin 2015). Also fairness as the other main principle of research ethics plays the role of an extrinsic epistemic value, since as a constitutive rule of the reward system it helps the scientific community to maintain its spirit and effort in truthseeking.

The intrinsic and extrinsic epistemic value-ladenness of science is compatible with the normative principle of objectivity. Arguments to the effect that sometimes the scientists are permitted or obliged to appeal to non-epistemic values in their acceptance of knowledge claims are not convincing. One of these arguments refers to the underdetermination of theories by empirical data, but a scientist always has the option of suspending judgment and searching for more relevant evidence to decide the matter (Niiniluoto 1999, p. 176). Another argument, due Richard Rudner (1953), suggests that the acceptance of a hypothesis should take into account the "inductive risk" in acting upon this hypothesis. But we need not assume with the "behaviouralists" or pragmatists that the cognitive acceptance of a hypothesis means the same as the decision to act as if the hypothesis were true (Niiniluoto 2012). Already Isaac 
Levi (1967) convincingly argued in his cognitive decision theory that the tentative acceptance of scientific hypotheses can be based upon their epistemic utilities - without appealing to other value judgments.

Here it is relevant to take up the distinctions between science and technology and between basic and applied research. ${ }^{2}$ Kitcher (2001) refers to Niiniluoto (1993), but notes that these distinctions are problematic or "not simple". In his reply to Antonio Bereijo, Kicther doubts the practical relevance of these distinctions, and tells that his discussion of the "Myth of Purity" was intended to undermine "a standard defense of insulating certain kinds of scientific research against critiques that invoke ethical, social, and political values" (see Gonzalez 2011, p. 376). So Kitcher is in fact interested in the third basic norm of research ethics, viz. responsibility. Again it is relevant to separate the motivations of individual scientists and the institutional norm. In this respect, the distinctions help to show that different types of research and technology are value-laden in quite different ways (see Niiniluoto, 2014).

The OECD distinction between research ("the pursuit of new knowledge") and development (the use of results of research "to develop new products, methods, and means of production") repeats the old Aristotelian distinction between scientia and techne. At least for a scientific realist, this $\mathrm{R} \& \mathrm{D}$ divide matches with the distinction between science and technology: science seeks knowledge, technology designs artifacts, and development is science-based technology (cf. Niiniluoto 1984). Pragmatists and instrumentalists, who see science as a problem-solving rather than a truth-seeking activity, instead tend to blur the difference between R and D with new catchword "technoscience" (cf. Niiniluoto 2016).

The OECD handbook makes a further distinction between basic and applied research. The former (fundamental, curiosity-driven, blue skies research) seeks knowledge for its own sake "without the aim of specific application", the latter pursues "knowledge with the aim of obtaining a specific goal". The historical background of this divide can be found in Francis

\footnotetext{
${ }^{2}$ One of the referees fears that the treatment of knowledge production in terms of epistemic values may appear detached from "any overarching conception of humanity". I argue below that applied research and technology (even though their truth claims are grounded in epistemic criteria as well) leave ample room for ethical, ecological, and social values which serve to promote the survival and well-being of humanity. Democratic science policy with educated citizens is the best warrant for the implementation of such humane values.
} 
Bacon's early $17^{\text {th }}$ century program of the scientification of technology: "knowledge is power" in the sense that knowledge about causal laws helps us to produce desired things or to prevent undesired outcomes. The idea of systematically searching such practical knowledge was realized - historically parallel to applied arts - in the late $19^{\text {th }}$ century by the emerging engineering sciences and agricultural sciences (cf. Roll-Hansen 2017).

One way of looking at these conceptual distinctions is in terms of the related value goals. Pure science and applied science both seek knowledge, but for the former justified truths have intrinsic value while the latter is interested in their instrumental value. On the other hand, various kinds of practical utilities are relevant and appropriate in technology and more generally in human decision-making in politics, economy, and everyday life. Each artifact has its intended use (or "final cause" in Aristotle's sense), and possibly some unintended side-effects. Different branches of technology have their own specific goals, such as power, speed, and security for airplane engineering. Such values can be used as goals to be pursued by means of design methods. In Technology Assessment (TA), they serve as criteria of the success of technical tools and products. As a summary of such assessment, one can propose the formula $\mathrm{TA}=6 \mathrm{E}+\mathrm{S}$ (see Niiniluoto 1997). Here the six E's are

- Effectiveness (ability to achieve the intended use or function)

- Economical efficiency (cost-benefit success)

- Ergonomics (relations to the health of users)

- Ecology (relations to the health of the natural environment)

- Esthetics (beauty)

- Ethics (good or bad by moral standards).

Finally, S refers to the social impact of technical tools. The formula of TA shows that technological products are value-laden in quite different sense that the epistemic search for truth in science.

Basic research seeks informative truths which describe and explain reality. Applied research combines truth-seeking with the requirement of relevance. Typically it is practiced as a design science which seeks knowledge about means - ends relations, so that its results 
can be expressed as technical norms of the form

(TN) If you want A, and believe that you are in situation B, then you ought to do X.

(See Niiniluoto 2014.) This notion of design science covers a variety of fields like evidencebased clinical medicine, synthetic biology, genetic engineering, nanotechnology, applied social sciences, and policy studies (see Niiniluoto 2013). It is important to note that the justification of technical norms can be objective or value-neutral in the sense that it relies on theoretical and empirical information about the causal or lawlike connection between $\mathrm{X}$ and A in situation B. Such claims, which can be assessed by epistemic utilities, are derived from basic research, which gives a fair reason to support independent fundamental research in science policy - instead of the currently common rhetoric in favor of innovations with shortterm benefits.

Further, in the justification of a technical norm TN a commitment of the researcher to the conditional value A is not needed. Technical oughts are binding only for those who accept the antecedent value premise of the technical norm. For example, a pacifist may accept the results of military studies, and a militarist may approve the conditional conclusions of peace research - even though they will disagree in the social and political relevance of their respective fields. Still, the conditional norm TN is indispensably value-laden in the sense that it essentially involves a value premise as its antecedent. Hence, design sciences do not satisfy any principle of value-freedom which would require that all value terms are excluded from their language.

This account of applied design sciences allows that any social value could take the place of the value A of a technical norm. Such values are not criteria for accepting the theories or models which are used to justify the claims of design sciences, but rather they are antecedents of technical norms or conditional recommendations of action. The value $\mathrm{A}$ is typically not a motivation of an individual researcher, but an institutional motive e.g. for defense, health, welfare, agriculture, or environmental protection. The promotion of such motives usually takes place in special institutes of applied and sectorial research.

It can be suggested that this model of design sciences gives a conceptual tool of 
making a difference between conservative and radical inquiry - something that Fuller strives for in his discussion of descriptive and revisionary SE. Basic sciences are indeed descriptive and explanatory, while design sciences give rules for changing the world. Especially in the social sciences the end A may be conservative (preservation of status quo), reformist (Popperian piecemeal social engineering) or emancipatory (radical changes in the social order). For example, the aim A may be to improve the conditions of politically marginalized or socially oppressed groups of people (see Niiniluoto 1999, p. 251, for a proposal of applied feminist research). Further, it is important to observe that the division between the situation B and manipulable factors $\mathrm{X}$ in $\mathrm{TN}$ is not only relative to our abilities, but sometimes also to our value-laden decision to keep B constant and to let X change. For example, political economics may decide to accept the framework of market economy as given, while revolutionary Marxists propose that the capitalist system is abolished.

\section{Science, Experts, and Democracy}

The relation between science and democracy should be an important theme in the discussion about the social aspects of knowledge. Goldman (1999) includes a chapter on democracy, where he points out that the successful functioning of representative democracy depends on the acquisition of knowledge by particular actors or role-players. In other words, it is important that political decision-makers in governments and parliaments are well informed and properly advised about the up-to-date results of science.

Philip Kitcher's work Science, Truth, and Democracy (2001) opens a much broader perspective on the science -democracy relations, and thereby gives an important service to the program of Analytic Social Epistemology. (Note, however, that Kitcher is not included in the bibliography of Haddock et al. 2010.) Kitcher's project describes "well-ordered science" which seeks "significant truths", where scientific significance depends on our contingent but "enlightened" interests. This is comparable to Fuller's (2012) insistence that Critical Social Epistemology should investigate "which truths are worth pursuing". But no compromise between ASE and CSE has been achieved so far. Even though Kitcher is willing to reject the "scientistic" view of the scientific community as "secular priesthood", Fuller (2004) bluntly 
claims that Kitcher, failing to register conflict between science and society, gives science the status of the "guarantor of social order" with "a church-like authority".

Fuller's own project of the "democratization of knowledge" is "to make all things knowable to everyone". CSE should find "more efficient means of reaching comparable and superior epistemic ends that would allow, at the limit, anyone to know everything”. This means that the public distribution of knowledge should be democratic (see also Fuller, 1993). Recall that when CSE was launched in 1987, we did not yet have the World Wide Web. Today the digital revolution and the internet have inspired the program of "open science" or "Science 2.0", which aims to make all scientific publications available free online. This is an extension of Merton's principle of "communism" to the Information Age. But nevertheless Fuller's ideal state where everyone could know everything is utopian, since the open accessibility of all scientific information would not guarantee that anyone could understand this information. So the free electronic distribution of scientific information should be complemented with a program of providing science-based education for all. Likewise Fuller's superutilitarianism in developing a new species Homo 2.0 appeals to the values of future generations in a speculative manner.

Longino (2002b), whose social norms for effective critical interaction within the scientific community have a democratic flavor, correctly observes that "Kitcher wants to democratize science policy, not science", since his democratic deliberations concern the research agenda and the application of scientific knowledge. It is, indeed, appropriate to distinguish the epistemological problem of accepting scientific hypotheses from other stages of knowledge production. Kitcher's well-ordered science is concerned with decisions by groups "receiving tutoring from scientific experts and accepting input from all perspectives", but this ideal deliberation deals with the allocation of resources, choice of pursued projects, and the translation of results into practical consequences - and these questions belong to democratic science and technology policy rather than science itself (cf. Niiniluoto 1999, p. 298).

Kitcher's "enlightened democracy" is intended to be a middle way between "vulgar democracy" (based on majority vote) and elitism (based on internal or external experts). However, as an ideal it appears to be unrealistic or too far removed from the actual practices 
of decision making in science and technology policy. The organization of inquiry is largely meritocratic, but at the same time guided by peer review processes. In many democratic countries the parliaments allocate resources to independent universities and research funding organizations, which then distribute money to researchers and research project on the basis of their scientific quality. Assessment of such projects is typically made by panels consisting of peers or scholars in the same field. This model is followed also within the European Union by the European Research Council (ERC) which finances high-quality basic research. Another stream of funding for strategic and applied research is targeted to projects which serve some socially relevant function, such as economic competitiveness, health care, and environmental protection. It is this area where Kitcher's notion of well-ordered science has its primary application, but even there socially motivated general themes have to translated into research questions by skillful scientists. Results of research are then applied in the innovation activities of companies. In most countries, the major part of $R \& D$ goes to $D$, i.e., technological projects of developing new commercial products. Even though business firms may receive some public support for their activities, they make their own decisions about the applications of scientific results by following the rules of the market economy.

New trends, which to some extend modify this traditional division of labor, include the model of the so called "mode 2 " research and "user-driven" innovation, where the researchers and users work together in the same teams (Gibbons et al. 1994). A similar idea is followed in consumer panels and consensus conferences, where scientific experts and the potential users of new technological tools and services meet each other. Such panels may also assess the risks of new technological products and methods (e.g. power plants, new pharma, medical treatments), so that they combine the opinions of scientific experts and ordinary citizens (see Shrader-Frechette 1985). In this way, technology assessment taking into account all the dimensions of the formula $\mathrm{TA}=6 \mathrm{E}+\mathrm{S}$ (see Section 5) can - and should - have some democratic elements. This is one way of interpreting Fuller's (1993) "democratic presumption" that "science can be scrutinized and evaluated by appropriately informed lay public". But this is quite different from epistemological questions about science, so that we again see why it is important to have a distinction between science and technology (see Section 5). 
Finally, let us turn to what Goldman's considers as the "real epistemological question" of justifying truth claims (cf. Haddock et al. 2010). Paul Feyerabend's (1987), p. 59, principle of "democratic relativism" asserts that "citizens and not special groups have the last word in deciding what is true or false, useful or useless in society". We have already seen that citizens indeed should have an important role in deciding what is useful or useless in society, i.e., in science and technology policy. But truth is not "decided" by citizens, nor by the scientist, either, but determined by facts as truth makers (Niiniluoto 1999, p. 297). For the scientific realists, the most reliable way of seeking truth is the use of the self-corrective method within the scientific community. Thus, for the realists working in the program of ASE the relevant question here concerns the process of finding a consensus about a knowledge claim in the scientific community. Essentially a generalization of the same problem is in the agenda of CSE. Fuller opens his 1988 book with the following question:

\footnotetext{
"How should the pursuit of knowledge be organized, given that under normal circumstances knowledge is pursued by many human beings, each working on a more or less well-defined body of knowledge and each equipped with roughly the same imperfect cognitive capacities, albeit with varying degrees of access to one another's activities?”
}

Useful surveys of the procedures of closing disputes in science are given by Engelshardt and Caplan (1987). The prospect of resolution of such controversies may be limited in politically sensitive social sciences, where the parallel existence of rival schools without much mutual communication is quite normal, so that further studies in the humanities should be added to the agenda of social epistemology.

The process of seeking consensus in science typically involves several stages. (i) Students receive scientific education and become members of the scientific community by defending their Ph.D. theses. (ii) Post-doctoral researchers advance in their academic career by being appointed as professors in universities. (iii) Researchers and research groups apply grants for pursuing their projects. (iv) Researchers submit their articles to scientific journals and congresses which accept or reject them on the basis of referees' reports. (v) Published 
articles are critically debated by other scholars.

Here the preparatory stages (i) - (iii) are non-symmetric in the sense that they involve the evaluation of candidates by experts. Stage (iv), which is the characteristic way of quality assurance by the scientific community, uses peer review as its method. The author and the referee as "peers" are in principle on the same level of competence, but their identities are not revealed to each other. (v) is the stage of open critical discussion, emphasized by Popper (1963). It sometimes leads to an agreement by all or most investigators, but such a temporary consensus can be challenged at any time by scholars with new empirical evidence or theoretical viewpoints. In this sense, science does not accept any incorrigible dogmas or permanent authorities. But still some scholars, whose publications are appreciated and cited by their colleagues, can gain cognitive authority as opinion leaders within their own disciplines.

Critical discussion in the scientific community is not based on voting, but rather the strongest argument should win. Against "standpoint theories", which claim that some special group has a privileged position in knowledge-seeking, both Kitcher (2001) and Longino (2002a) defend the pluralist stance that adequate and diverse representation of different perspectives is necessary for critical discussion. But both admit that "vulgar democracy" should be avoided. Longino, who requires that all members of the scientific community should be regarded as capable of contributing to its critical dialogue, grants that equality should "tempered", since members of the community differ in their intellectual capacity and their cognitive authority with respect to domain-specific questions (ibid., pp. 132-133). So the stage (v) of consensual acceptance of knowledge claims is not democratic by its nature. Still, the requirement of diversity suggests that the membership in the scientific community should be democratized: a career in science should be open to all who have enough talent and motivation - independently of their nationality, gender, and wealth (Niiniluoto 1999, p. 298).

Can the models of group knowledge, discussed in Section 1, handle this kind of consensus with only a "tempered equality"? The problem with the institutional approach of ASE is that most of its applications have followed Lewis (1969) in treating collective acceptance in terms of egalitarian mutual beliefs or common knowledge. The concept of mutual belief or mutual acceptance in the sense of shared we-beliefs (3) is not adequate to 
reflect the cognitive authority relations that are essential in the production of scientific knowledge. But it can be argued that Tuomela's (1995) concept of proper group beliefs, with some modifications (see Section 1), can be employed to give a useful account of science as collective knowledge (see Niiniluoto 2003).

The need of an alternative to cognitive egalitarianism has been outlined by Hilary Putnam (1975) in his discussion of the "division of linguistic labor": the distinction between terms like "elm" and "beech", or the application of the term "gold", is known only to a subset of the speakers of English. The linguistic community can be considered as a collective body, but it divides the "labor" of knowing and employing the meanings of some terms: there are experts who know the extension of "gold", and we others use this term in a way that depends on our "structured cooperation" with the experts. Scientific practices are also based upon the “division of cognitive labor” (cf. Kitcher 1993, Ch. 8). Polanyi (1967), p. 70, expressed this vividly by asking how the results independent inquiries sustain the systematic unity of science. Elsewhere he pointed out that each scientist "independently plays his part in maintaining this tradition over an immense area of scientific enquiry of which he knows next to nothing" primarily through "a chain of mutual appreciation" (Polanyi 1964, p. 16). Thus, the unity of science is based on the joint commitment to a method that allows each scientists to be "criticized by their own neighbors". Hegselmann and Krause (2006) are able show by their simulations that consensus on the truth can be reached on relatively mild conditions.

For these reasons, the institutional definition (7) of scientific knowledge should be based upon the definition (4) of proper group beliefs. But in the case of scientific knowledge, it should be formulated with variable groups of operative members, i.e., each different subgroup has authority with respect to its own domain of research. For example, if we wish to know something about distant galaxies, we consult radio astronomers, or in matters about medieval cities we ask advice from urban historians. We trust these specialists, since we know that they are committed to the use of the critical methods of inquiry. What the scientific community collectively knows is based upon the knowledge of such disciplinary subgroups. But each subgroup in turn formulates its mutual beliefs on the basis of its best experts who usually are the most appreciated and cited scholars in the relevant field.

While this kind of approach can be included in the program of ASE, Fuller has in 
practice acted against it by writing two books which support or at least try to give "a fair run" to the pseudoscientific Intelligent Design hypothesis against Darwinism (see Fuller 2008).

Assume that the scientific community G (at some moment of time) can be covered by the union of the subgroups $G_{1}, \ldots, G_{k}$, so that each $G_{i}$ has its own legitimate domain $D_{i}$ of research questions. These subgroups correspond to subdisciplinary areas of science. The groups may have common individual members, especially for interdisciplinary problems, but the corresponding research domains should be disjoint. Assume that each $\mathrm{G}_{\mathrm{i}}$ has authority in $\mathrm{G}$ over its own domain $\mathrm{D}_{\mathrm{i}}$ in the following sense:

(9) $\quad \mathrm{MB}_{\mathrm{G}}$ (if $\mathrm{p}$ belongs $\mathrm{D}_{\mathrm{i}}$ and $\mathrm{G}_{\mathrm{i}}$ mutually believes that $\mathrm{p}$, then $\mathrm{G}$ believes that $\mathrm{p}$ )

(cf. (4)). We can further assume that, following (4) again, each group $\mathrm{G}_{\mathrm{i}}$ forms its mutual beliefs by relying on its best authorities or expert $\mathrm{E}_{\mathrm{i}}$. Then, given these authority assumptions, the scientific community $G$ believes that $p$ if and only if $p$ belongs to domain $D_{i}$ and the relevant group $\mathrm{G}_{\mathrm{i}}$ mutually believes that $\mathrm{p}$. If the group $\mathrm{G}_{\mathrm{i}}$ suspends judgment about some important research problem, then there is no collective scientific knowledge about that matter.

Even though the members of the scientific community have mutual respect to each other as scientists, the authority structure (9) is different from the Lehrer - Wagner (1981) consensus theory: given a specific research problem in $\mathrm{D}_{\mathrm{i}}$, there is no chain of positive respect going through the whole community $\mathrm{G}$, but rather all the members of $\mathrm{G}$ have positive respect toward the recognized experts in $G_{i}$.

Scientific expertise in research domains concerns claims in that area, but also attempts to justify these claims by observational, experimental, or theoretical means. It is part of the competence of the members of $\mathrm{G}_{\mathrm{i}}$ to recognize what counts as evidence for claims in domain $\mathrm{D}_{\mathrm{i}}$. Hence, the authority assumption (9) applies also to cases where proposition $\mathrm{p}$ is replaced by justification claims of the form $J(j, p)$. According to (9), if the experts in $E_{i}$ announce their evidence for $\mathrm{p}$ (or publish it as open data), after having critically discussed it between themselves, the other members of the scientific community ought to accept it. But even in cases where these other members cannot understand or check that evidence (e.g., go through 
a proof of a mathematical theorem, repeat themselves an experiment testing a theory), they ought to rely on the testimony of the experts.

This model is still idealized at least in assuming an effective (if not perfect) communication within the community G. But it is flexible in allowing the experts to change their consensus on the basis of new scientific evidence, provided by new observations or novel theoretical alternatives. Also all authority position within the scientific community are temporary. An expert group may lose old members and recruit new members. Assumption (9) only tells what happens when the authority is still secured. Sometimes authorities may be transferred as a result of a successful reduction of a problem area to another. Moreover, during scientific revolutions, the status of a group as an authority relative to its domain may be questioned by other members of the scientific community - and as a result the power relations within science as well as the contents of collective scientific knowledge are changed. In this way, dynamic changes in the content of scientific knowledge may be associated with transformations of social structures in the scientific community. ${ }^{3}$

Department of Philosophy, History, and Art Studies

P. O. Box 24

O0014 University of Helsinki

Finland

e-mail: ilkka.niiniluoto@helsinki.fi

\section{BIBLIOGRAPHY}

Apel, Karl-Otto (1980). Toward a Transformation of Philosophy. London: Routledge and Kegan Paul.

Ben-David, Joseph (1971). The Scientist's Role in Society: A Comparative Study. Englewood Cliffs: Prentice-Hall.

Campbell, Norman (1921). What is Science? London: Methuen.

\footnotetext{
${ }^{3}$ I am grateful to Finn Collin for useful comments on my comparison of ASE and CSE.
} 
Cevolani, Gustavo (2014). Truth Approximation, Belief Merging, and Peer Disagreement. Synthese 191, 2383-2401.

Collin, Finn (2011). Science Studies as Naturalized Philosophy. Dordrecht: Springer.

Cozzens, S. E. and Woodhouse, E. J. (1995). Science, Government, and the Politics Knowledge. In S. Jasanoff et al. (Eds.), Handbook of Science and Technology Studies (pp. 533-553). London: Sage.

Diéguez, Antonio (2011). Kitcher's Modest Realism: The Reconceptualization of Scientific Objectivity. In Gonzalez (2011), pp. 141-169.

Douglas, Mary (1986). How Institutions Think. Syracuse, NY: Syracuse University Press.

Engelshardt, H. T. Jr. and Caplan, A. L. (Eds.) (1987). Scientific Controversies: Case Studies in the Resolution and Closure of Disputes in Science and Technology. Cambridge: Cambridge University Press.

Feyerabend, Paul (1987). Farewell to Reason. London: Verso.

Fuller, Steve (1988). Social Epistemology. Bloomington, Ind.: Indiana University Press.

Fuller, Steve (1989). Philosophy of Science and its Discontents. Boulder, Col.: Westview Press.

Fuller, Steve (1993). Philosophy, Rhetoric, and the End of Knowledge: The Coming of Science and Technology Studies. Madison: University of Wisconsin Press.

Fuller, Steve (1997). Science. Buckingham: Open University Press.

Fuller, Steve (2003). Kuhn vs. Popper: The Struggle for the Soul of Science. Cambridge: Icon Books.

Fuller, Steve (2004). Descriptive vs. Revisionary Social Epistemology: The Former Seen by the Latter. Episteme 1, 23-34.

Fuller, Steve (2008). Dissent over Descent: Intelligent Design's Challenge to Darwinism. Thriplow: Icon.

Fuller, Steve (2012). Social Epistemology: A Quarter-Century Itinerary. Social Epistemology $26,267-283$.

Gibbons, Michael et al. (1994). The New Production of Knowledge: The Dynamics of Science and Research in Contemporary Societies. London: Sage.

Gilbert, Margaret (1989). On Social Facts. London: Routledge. 
Goldman, Alvin I. (1987). Foundations of Social Epistemics. Synthese 73, 109-144.

Goldman, Alvin I. (1999). Knowledge in a Social World. Oxford: Clarendon Press.

Goldman, Alvin I. (2010). Social Epistemology. In E. N. Zalta (Ed.), The Stanford Encyclopedia of Philosophy (Summer 2010 Edition), URL = http://plato.stanford.edu/archives/sum2010/enties/epistemology-social/

Goldman, Alvin I. and Whitcomb, Dennis (Eds.) (2011). Social Epistemology: Essential Readings. Oxford: Oxford University Press.

Gonzalez, Wenceslao (Ed.) (2011). Scientific Realism and Democratic Society: The Philosophy of Philip Kitcher. Amsterdam: Rodopi.

Habermas, Jürgen (1998). On the Pragmatics of Communication. Cambridge: Polity Press. Haddock, Adrian, Millar, Alan and Pritchard, Duncan (Eds.) (2010). Social Epistemology. Oxford: Oxford University Press.

Hagstrom, W. (1965). The Scientific Community. New York: Basic Books.

Hegselmann, Rainer and Krause, Ulrich (2006). Truth and Cognitive Division of Labor: First Steps Towards a Computer Aided Social Epistemology. Journal of Artificial Societies and Social Simulation 9, URL = http:// jasss.soc.surrey.ac.uk/9/3/10.html.

Kitcher, Philip (1993). The Advancement of Science: Science without Legend, Objectivity without Illusions. Oxford: Oxford University Press.

Kitcher, Philip (2001). Science, Truth, and Democracy. New York: Oxford University Press. Kitcher, Philip (2002). The Third Way: Reflections of Helen Longino's The Fate of Knowledge. Philosophy of Science 69, 549-559.

Kitcher, Philip (2011). Science in a Democratic Society. In Gonzalez (2011), pp. 95-112.

Kuhn, Thomas S. (1970). The Structure of Scientific Revolutions, 2nd ed. Chicago: The University of Chicago Press.

Kusch, Martin (1997). The Sociophilosophy of Folk Psychology. Studies in History and Philosophy of Science 28, 1-25.

Kusch, Martin (2011). Social Epistemology. In S. Bernecker and D. Pritchard (Eds.), The Routledge Companion to Epistemology (pp. 873-884). London and New York: Routledge.

Kusch, Martin (2018). Scientific Realism and Social Epistemology. In J. Saatsi (Ed.), The 
Routledge Handbook of Scientific Realism (pp. 261-275). London: Routledge. Lagerspetz, Eerik (1989). A Conventionalist Theory of Institutions. Acta Philosophica

Fennica 44, Helsinki: The Philosophical Society of Finland.

Lehrer, Keith.and Wagner, Carl (1981). Rational Consensus in Science and Society: A Philosophical and Mathematical Study. Dordrecht: D. Reidel.

Levi, Isaac (1967). Gambling With Truth: An Essay on Induction and the Aims of Science.

New York: Harper \& Row.

Lewis, David (1969). Convention: A Philosophical Study. Cambridge, Mass.: Harvard University Press.

Longino, Helen E. (1990). Science as Social Knowledge: Values and Objectivity in Scientific Inquiry. Princeton, NJ.: Princeton University Press.

Longino, Helen E. (2002a). The Fate of Knowledge. Princeton, NJ.: Princeton University Press.

Longino, Helen (2002b). Reply to Philip Kitcher. Philosophy of Science 69, 573-577.

Merton, Robert S. (1973). The Sociology of Science: Theoretical and Empirical Investigations. Chicago: The University of Chicago Press.

Niiniluoto, Ilkka (1984). Is Science Progressive?,Dordrecht: D. Reidel,.

Niiniluoto, Ilkka (1987). Truthlikeness. Dordrecht: D. Reidel,.

Niiniluoto, Ilkka (1993). The Aim and Structure of Applied Research. Erkenntnis 38, 1-21.

Niiniluoto, Ilkka (1997). Technology Policy in a Democratic State. In S. Hellsten, M.

Kopperi, and O. Loukola (Eds.), Taking the Liberal Challenge Seriously (pp. 192204). Aldershot: Ashgate.

Niiniluoto, Ilkka (1999). Critical Scientific Realism. Oxford: Oxford University Press.

Niiniluoto, Ilkka (2003). Science as Collective Knowledge. In M. Sintonen, P. Ylikoski and K. Miller (Eds.), Realism in Action (pp. 269-278). Dordrecht: Kluwer.

Niiniluoto, Ilkka (2006). World 3: A Critical Defence. In I. Jarvie, K. Milford and D. Miller (Eds.), Karl Popper: A Centenary Assessment II (pp. 59-69). Aldershot: Ashgate.

Niiniluoto, Ilkka (2007). Ethical Issues of Research and Education. In K Tirri (Ed.), Values and Foundations of Gifted Education (pp. 9-14). Bern: Peter Lang.

Niiniluoto, Ilkka (2011). Revising Beliefs Toward the Truth. Erkenntnis 75, 165-181. 
Niiniluoto, Ilkka (2012). The Foundations of Statistics: Inference vs. Decision. In D. Dieks et al. (Eds.), Probabilities, Laws, and Structures (pp. 29-41). Springer: Dordrecht.

Niiniluoto, Ilkka (2013). On the Philosophy of Applied Social Sciences. In H. Andersen et al. (Eds.), New Challenges to Philosophy of Science (pp. 265-274). Springer: Dordrecht. Niiniluoto, Ilkka (2014). Values in Design Sciences. Studies in History and Philosophy of Science 46, 11-15.

Niiniluoto, Ilkka (2016). Science vs. Technology: Difference or Identity? In M. Franssen et al. (Eds.), Philosophy of Technology after the Empirical Turn (pp. 93-106). Switzerland: Springer.

Peirce, Charles S. (1878a). The Fixation of Belief. In Collected Papers, vol. 5, 1931-35. Cambridge, Mass.: Harvard University Press.

Peirce, Charles S. (1878b). The Doctrine of Chances. In Collected Papers, vol. 2, 1931-35. Cambridge, Mass., Harvard University Press.

Polanyi, Michael (1964). Science, Faith and Society. Chicago: The University of Chicago Press.

Polanyi, Michael (1967). The Tacit Dimension. New York: Doubleday, Garden City.

Popper, Karl.R. (1963). Conjectures and Refutations: The Growth of Scientific Knowledge. London: Routledge \& Kegan Paul.

Popper, Karl R. (1972). Objective Knowledge: An Evolutionary Approach. Oxford: Oxford University Press.

Quinton, Anthony (2004). Two Kinds of Social Epistemology. Episteme 1, 7-9.

Rolin, Kristina (2015). Values in Science: The Case of Scientific Collaboration. Philosophy of Science 82, 157-177.

Roll-Hansen, Nils (2017). A Historical Perspective on the Distinction Between Basic and Applied Science. Journal for General Philosophy of Science 48, 535-551.

Shrader-Frechette, Kristin (1985). Technology Assessment, Expert Disagreement and Democratic Procedures. In P. Durbin (Ed.), Research in Philosophy and Technology (pp. 103-129). Greenwich, GT: JAI Press,,.

Searle, John (1995). The Construction of Social Reality. New York: The Free Press. Shapin, Steven and Schaffer, Simon (1985). Leviathan and the Air-Pump: Hobbes, Boyle and 
the Experimental Life. Princeton: Princeton University Press.

Tambolo, Luca (2014). Pliability and Resistance: Feyerabendian Insights into Sophisticated Realism. European Journal for Philosophy of Science 4, 197-213.

Tuomela, Raimo (1984). A Theory of Social Action. Dordrecht: Reidel.

Tuomela, Raimo (1995). The Importance of Us: A Philosophical Study of Basic Social Notions. Stanford: Stanford University Press.

van Ditmarch, Hans, van der Hoek, Wiebe, and Kooi, Barteld (Eds.) (2007). Dynamic Epistemic Logic. Dordrecht: Springer.

Way, K. Brad (2007). Who has Scientific Knowledge? Social Epistemology 21, 335-345. Ziman, John (1994). Prometheus Bound: Science in a Dynamic Steady State. Cambridge: Cambridge University Press. 